\title{
Bioactivity of essential oils extracted from Cupressus macrocarpa branchlets and Corymbia citriodora leaves grown in Egypt
}

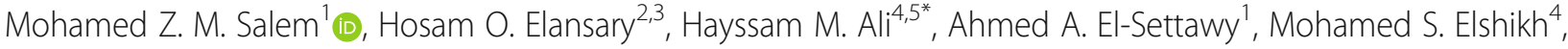
Eslam M. Abdel-Salam ${ }^{4}$ and Krystyna Skalicka-Woźniak ${ }^{6}$

\begin{abstract}
Background: Cupressus macrocarpa Hartw and Corymbia citriodora (Hook.) K.D. Hill \& L.A.S. Johnson, widely grown in many subtropical areas, are used for commercial purposes, such as in perfumery, cosmetics, and room fresheners. Their potential as a source of antimicrobial compounds may be useful in different applications.

Methods: The chemical composition of essential oils (EOs) from C. macrocarpa branchlets and C. citriodora leaves was analyzed by using gas chromatography-mass spectrometry (GC/MS). Antibacterial and antifungal activities were assessed by the micro-dilution method to determine the minimum inhibitory concentrations (MICs), and minimum fungicidal concentrations (MFCs), and minimum bactericidal concentrations (MBCs). Further, the antioxidant capacity of the EOs was determined via 2,2'-diphenypicrylhydrazyl (DPPH) and $\beta$-carotene-linoleic acid assays.

Results: Terpinen-4-ol (23.7\%), a-phellandrene (19.2\%), a-citronellol (17.3\%), and citronellal were the major constituents of EO from C. macrocarpa branchlets, and $a$-citronellal (56\%), a-citronellol (14.7\%), citronellol acetate (12.3\%), isopulegol, and eucalyptol were the primary constituents of EO from C. citriodora leaves. Antibacterial activity with MIC values of EO from C. citriodora leaves was ranged from $0.06 \mathrm{mg} / \mathrm{mL}$ to 0 . $20 \mathrm{mg} / \mathrm{mL}$, and $\mathrm{MBC}$ from $0.12 \mathrm{mg} / \mathrm{mL}$ against E. coli to $0.41 \mathrm{mg} / \mathrm{mL}$. EO from C. macrocarpa branchlets showed less activity against bacterial strains. The MIC values against tested fungi of the EO from $C$. citriodora ranged from 0.11 to $0.52 \mathrm{mg} / \mathrm{mL}$ while for EO from C. macrocarpa from 0.29 to $3.21 \mathrm{mg} / \mathrm{mL}$. The MIC and MFC values of EOs against $P$. funiculosum were lower than those obtained from Ketoconazole (KTZ) (0.20; 0.45 ; 0.29 and $0.53 \mathrm{mg} / \mathrm{mL}$, respectively, vs 0.21 and $0.41 \mathrm{mg} / \mathrm{mL}$. Antioxidant activity of the EO from C. citriodora was higher than that of the positive control but lower than that of the standard butylhydroxytoluene (BHT) $\left(\mathrm{I} \mathrm{C}_{50}=5.1 \pm 0.1 \mathrm{\mu g} / \mathrm{mL}\right)$.
\end{abstract}

Conclusion: The results indicate that the EO from Egyptian trees such as C. citriodora leaves may possesses strong bactericidal and fungicidal activities and can be used as an agrochemical for controlling plant pathogens and in human disease management which will add crop additive value.

Keywords: Antibacterial activity, Antifungal activity, Antioxidant activity, Corymbia citriodora, Cupressus macrocarpa, Essential oil

\footnotetext{
* Correspondence: hayhassan@ksu.edu.sa

${ }^{4}$ Botany and Microbiology Department, College of Science, King Saud

University, P.O. Box 2455, Riyadh 11451, Saudi Arabia

${ }^{5}$ Timber Trees Research Department, Sabahia Horticulture Research Station,

Horticulture Research Institute, Agriculture Research Center, Alexandria, Egypt

Full list of author information is available at the end of the article
} 


\section{Background}

Essential oils (EOs) and their constituents have potential applications for use in food products as they have been shown to have antifungal, antibacterial, and antioxidant properties [1-6]. The side effects associated with synthetic antimicrobial and antioxidant products urged a global search for natural products, such as natural EOs, with multiuse options. EOs are moderate to strong antioxidants and preservatives used in food processing. They are also used as antimicrobial agents in food supplement production and the pharmaceutical industry $[2,7,8]$.

The "Cypress" plants belong to the family Cupressaceae and are grown in many subtropical areas for commercial purposes, such as ornamentation, and as a source of wood-building material [9, 10]. Cupressus macrocarpa is an evergreen tree up to 23-m tall with horizontal branches [11]. Leaf EO from this plant is used against rheumatism, whooping cough, and styptic problems [12]. Several authors [11, 13-17] have described the EOs of C. macrocarpa. Zavarin et al. [18] focused on monoterpenes found in oil needles, while Cool [16], focused on the sesquiterpene compounds. A larger amount of monoterpenes, as compared to sesquiterpenes or diterpenes, was detected in the EOs of the branchlets of C. macrocarpa [18]. The major compounds identified in volatile oil from the cone of C. macrocarpa Hartwig from Nilgiris, India were terpinel-4-ol, dinopol, $\alpha$-pinene, and $\beta$-pinene [11]. Recently Fahed et al. [19] reported that the EOs of $C$. macrocarpa has strong activity against specific dermal fungi.

Eucalyptus citriodora (Hook.) or Corymbia citriodora (Hook.) K.D.Hill \& L.A.S. Johnson is widely used in perfumery, cosmetics, and room fresheners. For example, extracts of dried leaves resulted by hot water are traditionally used for many purposes like antipyretic remedies, anti-inflammatory, and analgesic as well as for the symptoms of respiratory infections, such as cold, and flu [20, 21].

The EOs of C. citriodora can be used as an antibacterial, antifungal, anticandidal, antioxidant, and antitrypanosomal, and also have insecticidal, acaricidal, herbicidal, analgesic, and anti-inflammatory activities [21-26]. Citronellal, $\beta$-citronellol, and isopulegol are monoterpenoids reported as major components in the leaf EO of C. citriodora growing in Chandigarh, India [26, 27]. However, 6octenal was reported as the major constituent in the leaf oil of $C$. citriodora from Nigeria [25]; $\alpha$-pinene, $\beta$-pinene, sabinene, and $\alpha$-thujene were reported to be minor constituents [28]. 3-Hexen-1-ol, cis-geraniol, citronellol acetate, 5-hepten-1-ol, 2,6-dimethyl, and citronellal were the major components in the leaf $\mathrm{EO}$ of $C$. citriodora grown in Zoological Garden in Giza-Egypt [29]. The EO of $C$. citriodora (lemon-scented eucalyptus) showed a wide spectrum of antifungal activity as well as activity against various pathogenic bacteria and yeasts [22, 30-39] resulting in that the EOs of some plants, including C. citriodora, have significant insecticidal activity against Sitophilus zeamais, however, $50 \%$ of the efficacy was lost 8 days after treatment.

In the framework of our continuing research on the EO composition and biological activities of Egyptian medicinal plants, we aimed to evaluate the biological activity of the EOs of Corymbia citriodora leaves and Cupressus macrocarpa "Citriodora" branchlets. For the first time full analysis of essential oils from both plants collected in Egypt was done as well as full characteristic of their antibacterial, antifungal activities against set of Gram-plus, Gram-minus as fungus was done. Additionally, antioxidant potential was evaluated.

\section{Methods}

\section{Plant material}

Air-dried materials of Corymbia citriodora leaves, Myrtaceae (from a plantation located at AlexandriaCairo desert road (Albostan area), Alexandria, Egypt) and Cupressus macrocarpa Hartw branchlets "Citriodora" Cupressaceae (from Faculty of Agriculture Garden, Alexandria, Egypt) were used in the present study during 2016. The plants were identified by Prof. Ahmed A. El-Settawy (Head of Forestry and Wood Technology Department) and given the voucher numbers Zidan00312 and Zidan313, respectively at the Faculty of Agriculture, Alexandria University. The plants were further morphologically approved by Dr. Hosam Elansary at the department of Floriculture, Ornamental horticulture and Garden Design.

\section{Extraction of essential oils}

Samples of C. citriodora leaves and C. macrocarpa branchlets were cut into small pieces (100 g) and hydrodistillated for $3 \mathrm{~h}$, in a Clevenger apparatus [40]. The oil was collected and the mass of fresh weight of sample was measured (3.15 and $4.70 \mathrm{~mL} / 100 \mathrm{~g}$ fresh weight, from C. citriodora and C. macrocarpa, respectively). The oil was kept dry in sealed Eppendorf tubes and stored at $4{ }^{\circ} \mathrm{C}$ prior for chemical analysis.

\section{GC/FID and GC/MS analysis of the EO}

GC Ultra/Mass spectrophotometer ISQ (Thermo Scientific), a trace instrument equipped with an FID and a DB-5 narrow bore column (length $10 \mathrm{~m} \times 0.1 \mathrm{~mm}$ ID, 0.17- $\mu \mathrm{m}$ film thickness; Agilent, Palo Alto, CA, USA) was used. Following the same conditions as described by Salem et al. [41].

Identification of the constituents was performed using an MS library search $[42,43]$ as well as calcualting the Retention indices (RIs). Computer matching was performed with the Wiley 275.L and Wiley 7 n.L libraries. 
GC-MS analysis of each of triplicate samples was repeated three times.

\section{Antibacterial activities}

Both Gram-positive and Gram-negative bacteria were used for analyses. The Gram-positive bacteria included Bacillus cereus (clinical isolate), Listeria monocytogenes (ATCC 19113), Micrococcus flavus (ATCC 10240) and Staphylococcus aureus (ATCC 6538). The Gram-negative bacteria included Dickeya solani (D s0432-1), Escherichia coli (ATCC 35210), Pectobacterium atrosepticum (ATCC 33260), Pectobacterium carotovorum subsp. carotovorum (ATCC 15713), and Pseudomonas aeruginosa (D s0432-1). The microdilution method [44] was used to determine the MIC and minimum bactericidal concentration $(\mathrm{MBC})$. The concentration of the bacteria was adjusted to $1.0 \times$ $10^{5} \mathrm{CFU} / \mathrm{mL}$ by using sterile saline, and then stored at $4{ }^{\circ} \mathrm{C}$. The essential oils were added to $100 \mu \mathrm{L}$ Triptic Soy broth (TSB) containing a bacteria inoculum $\left(1.0 \times 10^{5} \mathrm{CFU} /\right.$ well $)$ in a microtiter plate, then the MICs and MBCs were determined. The microplates were incubated at $37{ }^{\circ} \mathrm{C}$ for $24 \mathrm{~h}$ in a rotary shaker.

A serial sub-cultivation of $2 \mu \mathrm{L}$ was placed in microtiter plates containing $100 \mu \mathrm{L}$ of TSB for each well and incubated for $24 \mathrm{~h}$ to determine the MIC and MBC. The optical density was measured using a microplate manager at $655 \mathrm{~nm}$. Experiments were completed in triplicate. Dimethyl sulfoxide (DMSO, 5\%) and streptomycin $(1 \mathrm{mg} / \mathrm{mL})$ were used as negative and positive controls, respectively.

\section{Antifungal activities}

The activities of EOs against several fungi, including Aspergillus flavus (ATCC 9643), A. ochraceus (ATCC 12066), A. niger (ATCC 6275), Candida albicans (ATCC 12066), Penicillium funiculosum (ATCC 56755) and $P$. ochrochloron (ATCC 48663) were examined. The cultures were renewed monthly and stored at $4{ }^{\circ} \mathrm{C}$. The microdilution method [44], was used to determine the minimum inhibitory concentration (MIC) and minimum fungicidal concentration (MFC) using a spore suspension concentration of $\left(1.0 \times 10^{5} \mathrm{CFU} / \mathrm{mL}\right)$ dilutions in 96-well microtiter plates. EOs were diluted to the desired concentrations in microplates containing Malt medium broth mixed with inoculum. The microplates were incubated at $28{ }^{\circ} \mathrm{C}$ for $72 \mathrm{~h}$ on a rotary shaker.

The lowest concentration that inhibits fungi growth at the binocular microscope level was defined as the MIC. The MFC was defined as the minimum concentration showing no visible growth, which is consistent with a 99.5\% killing of the original inoculum. Serial subcultivations $(2 \mu \mathrm{L})$ of essential oils were incubated at $28{ }^{\circ} \mathrm{C}$ for $72 \mathrm{~h}$ in microtiter plates containing $100 \mu \mathrm{L}$ of broth and inoculum were used to calculate the MIC. Ketoconazole (KTZ) $(1-3500 \mu \mathrm{g} / \mathrm{mL})$ was used as a positive control. The experiments were performed in triplicate.

\section{Antioxidant activity of the EOs}

To determine the free radical scavenging activity of the obtained EOs, the 2,2'-diphenypicrylhydrazyl (DPPH) method was employed [45] (absorbance at $517 \mathrm{~nm}$ ), as along with the $\beta$-carotene-linoleic acid assay [8] (absorbance at $470 \mathrm{~nm}$ ). A blank was prepared in the same manner as the samples and the antioxidant activities of the samples were compared with the blank and standard antioxidant, butylhydroxytoluene (BHT). All experiments were repeated twice in triplicates.

\section{Statistical analysis}

The values of the antibacterial, antifungal, and antioxidant activities of EO from C. citriodora leaves and $C$. macrocarpa branchlets are presented as mean \pm standard deviation (SD). Analysis of variance (ANOVA) was used to evaluate the differences between the groups. $P<0.05$ was considered significant.

\section{Results \\ Composition of the EOs}

The EO of Cupressus macrocarpa branchlets contains 19 compounds (Table 1). The major chemical constituents identified included terpinen-4-ol (23.7\%), $\alpha$-phellandrene (19.2\%), $\alpha$-citronellol (17.3\%), citronellal (6.6\%), Dcamphor (5.4\%), $\gamma$-terpinene (5.3\%), $\alpha$-terpinene (3.08\%), $\alpha$-myrcene (2.2\%), limonene (2.16\%), $\alpha$-terpineol (1.7\%), terpinolene (1.8\%), and $\alpha$-linalool (1.5\%).

Seventeen compounds were identified in the EO of $C$. citriodora leaves (Table 2). The major constituents were $\alpha$-citronellal (56.0\%), $\alpha$-citronellol (14.7\%), citronellol acetate (12.3\%), isopulegol (7.6\%), eucalyptol (2.0\%), citronellic acid (1.4\%), caryophyllene oxide (1.2\%), and $(+)$-rose oxide $(1.2 \%)$.

\section{Antibacterial activity}

The MIC values of EO from C. citriodora leaves ranged from $0.06 \mathrm{mg} / \mathrm{mL}$ against $E$. coli to $0.20 \mathrm{mg} / \mathrm{mL}$ against $S$. aureus, and those values were lower than the MIC values of streptomycin (Table 2). Additionally, activity of this oil was comparable or even higher than reference antibiotic in case of Agrobacterium tumefaciens or B. cereus. EO from C. macrocarpa branchlets showed less activity against bacterial strains. The MIC values ranged from $0.07 \mathrm{mg} / \mathrm{mL}$ against $E$. coli to $0.31 \mathrm{mg} / \mathrm{mL}$ against $S$. aureus. The $\mathrm{MBC}$ values of EO from C. citriodora ranged from $0.12 \mathrm{mg} / \mathrm{mL}$ against $E$. coli to $0.41 \mathrm{mg} / \mathrm{mL}$ against $S$. aureus, whereas, the values were between $0.15 \mathrm{mg} / \mathrm{mL} \quad(E . \quad c o l i)$ and $0.63 \mathrm{mg} / \mathrm{mL}$ (S. aureus) using $\mathrm{EO}$ from C. macrocarpa 
Table 1 Essential oil constituents of C. macrocarpa branchlets and C. citriodora leaves

\begin{tabular}{|c|c|c|c|}
\hline Constituent & $\mathrm{Rl}^{\mathrm{a}, \mathrm{b}}$ & $\begin{array}{l}\text { Percentage } \\
\text { C. macrocarpa }\end{array}$ & $\begin{array}{l}\text { Percentage } \\
\text { C. citriodora }\end{array}$ \\
\hline a-Pinene & 925 & - & 0.1 \\
\hline Thujene & 953 & 0.9 & 0.4 \\
\hline a-Myrcene & 985 & 2.2 & 0.1 \\
\hline a-Phellandrene & 1005 & 19.2 & - \\
\hline$a$-Terpinene & 1015 & 3.0 & - \\
\hline Eucalyptol/1,8-Cineole & 1017 & - & 2.0 \\
\hline m-Cymene & 1023 & 0.4 & - \\
\hline Limonene & 1031 & 2.1 & - \\
\hline Terpinolene & 1035 & 1.8 & - \\
\hline Melonal & 1037 & - & 0.9 \\
\hline$\gamma$-Terpinene & 1067 & 5.3 & - \\
\hline a-Linalool & 1089 & 1.5 & 0.4 \\
\hline (+)-Rose oxide & 1100 & - & 1.2 \\
\hline trans-2-menthenol & 1140 & 1.0 & - \\
\hline Isopulegol & 1145 & - & 7.6 \\
\hline D-Camphor & 1151 & 5.4 & - \\
\hline Citronellal & 1159 & 6.6 & - \\
\hline Borneol & 1175 & 0.1 & - \\
\hline Terpinen-4-ol & 1192 & 23.7 & 0.5 \\
\hline$a$-Terpineol & 1193 & 1.7 & 0.2 \\
\hline Piperitol & 1205 & 0.7 & - \\
\hline a-Citronellal & 1211 & - & 56.0 \\
\hline a-Citronellol & 1233 & 17.3 & 14.7 \\
\hline Citronellic acid & 1305 & 1.3 & 1.4 \\
\hline Cubebol & 1501 & - & 1.1 \\
\hline Citronellol acetate & 1511 & - & 12.3 \\
\hline Spathulenol & 1564 & - & 0.3 \\
\hline Caryophyllene oxide & 1571 & - & 1.2 \\
\hline Farnesol & 1696 & 0.4 & - \\
\hline
\end{tabular}

${ }^{\mathrm{a}} R /$ Retention Index

${ }^{b}$ Identification of the essential oil components was performed by comparison of mass spectra and Rls obtained in both columns with those of reference compounds and those of mass spectra libraries

branchlets. The EO of C. citriodora and C. macrocarpa showed noticeable activity against phytopathogenic bacteria including Pectobacterium atrosepticum, P. carotovorum, and Dickeya solani, which causes many diseases in potato production, such as the blackleg in the field and soft rot during storage. Furthermore, all MIC values reported against the potato pathogenic bacteria were lower than those reported for the negative control, streptomycin.

\section{Antifungal activity}

The antifungal activities of the EOs against several fungi are shown in Table 3. The MIC values of the EO from
C. citriodora ranged from $0.11 \mathrm{mg} / \mathrm{mL}$ (A. niger) to $0.52 \mathrm{mg} / \mathrm{mL}$ (P. funiculosum), while the MFC values ranged from $0.25 \mathrm{mg} / \mathrm{mL}(A$. niger) to $0.95 \mathrm{mg} / \mathrm{mL}(P$. funiculosum). The MIC values of the EO from C. macrocarpa ranging from $0.29 \mathrm{mg} / \mathrm{mL}$ (P. ochrochloron) to $3.21 \mathrm{mg} / \mathrm{mL}$ (C. albicans), and the MFC values ranged from $0.53 \mathrm{mg} / \mathrm{mL}$ (P. ochrochloron) to $>5 \mathrm{mg} / \mathrm{mL}$ (C. albicans). It was noted that the MIC and MFC values of EOs against $P$. funiculosum were lower than those obtained from KTZ. In addition, the EO from C. citriodora leaves showed more potency than the $\mathrm{EO}$ of C. macrocarpa needles against the tested fungi.

\section{Antioxidant activity}

The antioxidant activity of tested $\mathrm{EOs}\left(\mathrm{IC}_{50}=5.1 \pm 0.1\right.$ and $6.1 \pm 0.1 \mu \mathrm{g} / \mathrm{mL}$ for C. citriodora and C. macrocarpa, respectively) is lower than that of the standard BHT $\left(\mathrm{IC}_{50}=2.9 \pm 0.2 \mu \mathrm{g} / \mathrm{mL}\right)$ (Table 4$)$.

\section{Discussion}

Giatropoulos et al. [46] reported that sabinene (21.8\%), $\alpha$-pinene (19.5\%), terpinen-4-ol (18.9\%), $\gamma$-terpinene (7.9\%), and $\alpha$-terpinene (5.7\%) were the major components detected in the needle $\mathrm{EO}$ of $C$. macrocarpa grown in Athens, Greece. In India, the major compounds identified in EO of cones of C. macrocarpa were terpinel-4-ol (19.4\%), dinopol (15.6\%), $\alpha$-pinene (13.5\%), and $\beta$-pinene (12.1\%) [11]. Recent investigation of Fahed et al. [19] found similar major essential oil constitutes such as sabinene and terpinen-4-ol. The primary compounds in the volatile oils of fresh and dried leaves of $C$. macrocarpa (gold crest) grown at the north coast of Egypt were neral (31-35\%), hydroxy citronellal (12$16 \%)$, geraniol (3-4\%), piperitol (trans) (7-8\%), isobornyl isobutyrate $(0.7-6.6 \%)$, linalool $(0.6-5.2 \%)$, terpinyl acetate $(0.10-3.2 \%)$, myrcene $(0.22-2.6 \%)$, trans-ferruginol (0.3-2.25\%), abitol (0.4-2.18\%), and eugenol dihydro (0.1-1.3\%) [17]. In Argentina, C. macrocarpa oil was found to be composed of $\alpha$-pinene (20.2\%), sabinene (12.0\%), $p$-cymene (7.0\%), and terpinen-4-ol (29.6\%) [15]. C. macrocarpa oils are rich in sabinene (27.0, 23.3\%), $\alpha$-pinene (22.2, 19.8\%), and terpinen-4-ol (11.7, $14.7 \%)$ with moderate amounts of $\gamma$-terpinene (5.6, $5.1 \%)$, isophyllocladene (4.4, 4.9\%), myrcene (3.6, 3.2\%), $\beta$-pinene (2.6, 2.0\%), and phyllocladene (2.3, 2.0\%) [47].

In agreement with our results, Jang et al. [48] found that the major EOs constitutes of C. citriodora are $\alpha$ citronellal and isopulegol. Singh et al. [26] found that the major monoterpenoids detected in the EO of $C$. citriodora were citronellal (60.6\%), $\beta$-citronellol (12.5\%), and isopulegol $(8.1 \%)$. In addition, citronellal and $\beta$-citronellol were the major components in the leaf $\mathrm{EO}$ of $C$. citriodora [28]. However, the major component of the leaves of C. citriodora grown at the State of Ceará, 
Table 2 Minimum inhibitory (MIC) and bactericidal concentration (MBC) of the essential oil ( $\mathrm{mg} / \mathrm{mL}$ ) of Corymbia citriodora leaves Hook and C. macrocarpa branchlets

\begin{tabular}{|c|c|c|c|c|c|c|}
\hline \multirow[t]{2}{*}{ Bacterial strains } & \multicolumn{2}{|c|}{ Corymbia citriodora } & \multicolumn{2}{|c|}{ Cupressus macrocarpa } & \multicolumn{2}{|l|}{ Streptomycin } \\
\hline & $\mathrm{MIC}$ & $\mathrm{MBC}$ & $\mathrm{MIC}$ & $\mathrm{MBC}$ & $\mathrm{MIC}$ & $\mathrm{MBC}$ \\
\hline Agrobacterium tumefaciens & $0.16 \pm 0.01 d$ & $0.37 \pm 0.02 b$ & $0.23 \pm 0.01 b$ & $0.55 \pm 0.03 b$ & $0.23 \pm 0.03 a$ & $0.43 \pm 0.03 a$ \\
\hline Bacillus cereus & $0.08 \pm 0.01 e$ & $0.20 \pm 0.01 e$ & $0.12 \pm 0.01 e$ & $0.27 \pm 0.03 f$ & $0.08 \pm 0.02 e$ & $0.15 \pm 0.01 \mathrm{~g}$ \\
\hline Dickeya solani & $0.18 \pm 0.01 b$ & $0.29 \pm 0.01 d$ & $0.21 \pm 0.01 c$ & $0.38 \pm 0.03 c$ & $0.09 \pm 0.01 e$ & $0.19 \pm 0.01 d$ \\
\hline Escherichia coli & $0.06 \pm 0.01 f$ & $0.12 \pm 0.01 f$ & $0.07 \pm 0.01 f$ & $0.15 \pm 0.01 \mathrm{~g}$ & $0.12 \pm 0.01 c$ & $0.30 \pm 0.03 c$ \\
\hline Pectobacterium atrosepticum & $0.17 \pm 0.01 c$ & $0.31 \pm 0.01 c$ & $0.17 \pm 0.02 d$ & $0.30 \pm 0.03 e$ & $0.10 \pm 0.01 d, e$ & $0.18 \pm 0.00 f$ \\
\hline Pectobacterium carotovorum & $0.16 \pm 0.01 d$ & $0.29 \pm 0.03 c$ & $0.13 \pm 0.01 e$ & $0.31 \pm 0.03 d$ & $0.12 \pm 0.01 c$ & $0.22 \pm 0.01 \mathrm{e}$ \\
\hline Staphylococcus aureus & $0.20 \pm 0.01 a$ & $0.41 \pm 0.03 a$ & $0.31 \pm 0.01 a$ & $0.63 \pm 0.05 a$ & $0.21 \pm 0.01 b$ & $0.36 \pm 0.03 b$ \\
\hline
\end{tabular}

Means with the same letters within the same column are not significantly different $(p<0.05)$

Brazil, was $\beta$-citronellal (71.7\%) [49]. In contrast, 6octenal $(77.1 \%)$ was found to be a major component in the EO of C. citriodora grown in Nigeria [26], and $\alpha$-pinene (38.6\%), $\beta$-pinene (25.6\%), sabinene (19.6\%), and $\alpha$ thujene $(11.9 \%)$ were the major compounds contained in the EO of C. citriodora leaves from Paschim Vihar (New Delhi) [29]. Neo-isopulegol, citronellal, iso-isopulegol, citronellol, citronellyl acetate, and E-caryophyllene were the primary components in the $\mathrm{EO}$ of the plant from Benin [50]. Hussein et al. [51] found that $\alpha$-citronellal, $\alpha$-citronellol, citronellol acetate, and isopulegol were the major chemical constituents from C. citriodora leaf EO. 1.8-cineole and $\alpha$-pinene were the primary components in the EO from $C$. citriodora grown in Zerniza and Souinet Arboreta (North West and North Tunisia) [52]. Interestingly, 6-octenal was not found in our study.

Citronellal and citronellol found in the EO of C. citriodora may be responsible for both its antimicrobial activity and antioxidant activity [24, 26, 53, 54]. Elaissi et al. [52] reported inhibition zone values ranging from $10.0 \pm$ $0.0 \mathrm{~mm}$ to $7.7 \pm 0.6 \mathrm{~mm}$ against $E$. coli ATCC 25922 and
S. aureus ATCC 25932, respectively, using absorbent disks impregnated with $10 \mu \mathrm{L}$ of $C$. citriodora oil.

The EO from C. citriodora showed higher antifungal activity than the positive control. These results are consistent with those of Ramezani et al. [22], who found that the volatile oil is more potent than the synthetic fungicide Mancozeb, and that C. citriodora oil strongly inhibits radial growth of Macrophomina phaseolina, Colletotrichum lindemuthianum, Fusarium oxysporum f. sp. lycopersici, Helminthosporium oryzae, Alternaria triticina, Rhizoctonia solani, and Alternaria solani with MICs ranging between 0.25 and $0.50 \mathrm{ppm}$. Fahed et al. [19] reported strong antifungal activities of the EOs of $C$. macrocarpa against specific fungi such as Trichophyton rubrum and it was associated mainly with major essential oil constitutes such as sabinene and terpinen-4-ol.

We found that The antioxidant activity are differed from those previously reported using the hydro-distillated EOs from the Indian C. citriodora with an $\mathrm{IC}_{50}$ of $425.4 \pm$ $6.79 \mu \mathrm{g} / \mathrm{mL}(\mathrm{DPPH})$ and $87.3 \pm 9.27 \mu \mathrm{g} / \mathrm{mL}$ (reduced activity) [26]. EO from C. citriodora leaves is rich in

Table 3 Minimum inhibitory concentration (MIC) and fungicidal concentration (MFC) of different leaf extracts (mg/mL) of Corymbia citriodora and Cupressus macrocarpa

\begin{tabular}{|c|c|c|c|c|c|c|}
\hline \multirow[t]{2}{*}{ Fungal strains } & \multicolumn{2}{|c|}{ Corymbia citriodora } & \multicolumn{2}{|c|}{ Cupressus macrocarpa } & \multicolumn{2}{|l|}{ KTZ } \\
\hline & $\mathrm{MIC}$ & MFC & $\overline{M I C}$ & MFC & MIC & MFC \\
\hline Aspergillus flavus & $0.21 \pm 0.01 f$ & $0.46 \pm 0.03 f$ & $0.31 \pm 0.03 \mathrm{~h}$ & $0.75 \pm 0.03 d$ & $0.23 \pm 0.01 c$ & $0.48 \pm 0.05 c$ \\
\hline Aspergillus ochraceus & $0.26 \pm 0.03 \mathrm{~d}$ & $0.51 \pm 0.01 e$ & $0.54 \pm 0.03 f$ & $1.43 \pm 0.10 c$ & $0.22 \pm 0.01 d$ & $0.43 \pm 0.03 d$ \\
\hline Aspergillus niger & $0.11 \pm 0.03 \mathrm{~h}$ & $0.25 \pm 0.03 \mathrm{~h}$ & $1.25 \pm 0.13 c$ & $>2 b$ & $0.10 \pm 0.03 \mathrm{~g}$ & $0.22 \pm 0.00 \mathrm{~g}$ \\
\hline Candida albicans & $0.25 \pm 0.01 e$ & $0.52 \pm 0.01 d$ & $3.21 \pm 0.15 a$ & $>5 a$ & $0.21 \pm 0.01 e$ & $0.43 \pm 0.03 d$ \\
\hline Fusarium oxysporum & $0.27 \pm 0.01 c$ & $0.58 \pm 0.03 c$ & $1.11 \pm 0.05 d$ & $>2 b$ & $0.26 \pm 0.01 b$ & $0.52 \pm 0.03 b$ \\
\hline Penicillium funiculosum & $0.52 \pm 0.05 a$ & $0.95 \pm 0.05 a$ & $0.73 \pm 0.05 e$ & $1.47 \pm 0.07 c$ & $2.01 \pm 0.11 \mathrm{a}$ & $3.65 \pm 0.01 a$ \\
\hline Penicillium ochrochloron & $0.20 \pm 0.01 \mathrm{~g}$ & $0.45 \pm 0.03 \mathrm{~g}$ & $0.29 \pm 0.01 \mathrm{~g}$ & $0.53 \pm 0.03 e$ & $0.21 \pm 0.01 e$ & $0.41 \pm 0.03 f$ \\
\hline Rhizoctonia solani & $0.37 \pm 0.01 b$ & $0.81 \pm 0.05 b$ & $>2 b$ & N.D. & $0.19 \pm 0.01 f$ & $0.42 \pm 0.03 e$ \\
\hline
\end{tabular}

N.D. Not detected

KTZ Ketoconazole

Means with the same letters within the same column are not significantly different $(p<0.05)$ 
Table 4 Essential oils DPPH and $\beta$-carotene-linoleic acid assay results

\begin{tabular}{lll}
\hline Sample & \multicolumn{1}{l}{$50, \mu \mathrm{g} / \mathrm{mL}$} & \\
\cline { 2 - 3 } & DPPH assay & $\beta$-Carotene-linoleic acid assay \\
\hline Corymbia citriodora & $5.1 \pm 0.1 \mathrm{~b}$ & $3.2 \pm 0.1 \mathrm{~b}$ \\
Cupressus macrocarpa & $6.1 \pm 0.1 \mathrm{C}$ & $4.0 \pm 0.1 \mathrm{c}$ \\
BHT & $2.9 \pm 0.2 \mathrm{a}$ & $2.6 \pm 0.1 \mathrm{a}$ \\
\hline
\end{tabular}

Values are expressed as mean of triplicate determinations \pm

standard deviation

BHT Butylated hydroxyltoluene

Means with the same letters within the same column are not significantly different $(p<0.05)$

monoterpenoids and thus, shows strong antioxidant activity $[26,53,54]$.

It was concluded that the volatile oils of $C$. citriodora may have tremendous potential as antimicrobial agents in food sciences in addition to their numerous uses and applications in pharmaceutical and medicinal areas [55].

\section{Conclusions}

The EO of C. macrocarpa branchlets primarily comprised terpinen-4-ol, $\alpha$-phellandrene, $\alpha$-citronellol, and citronellal, while in C. citriodora the oil consisted primarily of $\alpha$ citronellal, $\alpha$-citronellol, citronellol acetate, isopulegol, and eucalyptol. Moderate activity was found against the studied bacterial strain. However, the EO of C. citriodora leaves showed more potency than the C. macrocarpa branchlets did against the studied fungi. The EO of $C$. citriodora showed higher activity than the positive control did. Additionally, the antioxidant activity of tested EOs was lower than that of the standard BHT used.

\section{Abbreviations}

ANOVA: Analysis of variance; ATCC: American Type Culture Collection; BHT: Butylhydroxytoluene; CFU: Colony-forming unit; DMSO: Dimethyl sulfoxide; DPPH: 2,2'-diphenypicrylhydrazyl; El: Electron impact ionization; EO: Essential oil; FID: Flame Ionization Detector; GC/MS: Gas chromatography-mass spectrometry; HP: Hewlett Packard; $\mathrm{IC}_{50}$ : The concentration required to inhibit DPPH radical formation by 50\%; KTZ: Ketoconazole; MBC: Minimum bactericidal concentration; MFC: Minimum fungicidal concentration; MIC: Minimum inhibitory concentration; Rl: Retention index; SD: Standard deviation; TSB: Triptic Soy broth

\section{Acknowledgments}

The authors would like to extend their sincere appreciation to the Deanship of Scientific Research at king Saud University for its funding this Research group NO. (RG 1435-011).

\section{Funding}

The authors would like to extend their sincere appreciation to the Deanship of Scientific Research at king Saud University for its funding this Research Group NO. (RG 1435-011). This study was also supported by the Faculty of Agriculture, Alexandria University, Egypt.

\section{Availability of data and materials}

The datasets supporting the conclusions of this article are included within the article.

\section{Authors' contributions}

MZMS and HOE performed the in-vitro experiments, data as well as GC/MS analysis. HMA, ESAA participated in the study design and helped to draft the manuscript. MSE, and S-WK made substantial contributions to conception, design and interpretation of data and participated in writing the final manuscript. EMAS helped to improve the manuscript. All authors read and approved the final manuscript.

\section{Ethics approval and consent to participate}

This information is not relevant.

\section{Consent to publication}

This information is not relevant.

Competing interests

The authors declare that they have no competing interests.

\section{Publisher's Note}

Springer Nature remains neutral with regard to jurisdictional claims in published maps and institutional affiliations.

\section{Author details}

${ }^{1}$ Forestry and Wood Technology Department, Faculty of Agriculture (EL-Shatby), Alexandria University, Aflaton St., El-Shatby, P.O. Box 21545, Alexandria, Egypt. ${ }^{2}$ Department of Floriculture, Ornamental Horticulture and Garden Design, Faculty of Agriculture (El-Shatby), Alexandria University, Alexandria, Egypt. ${ }^{3}$ Department of Geography, Environmental Management and Energy Studies, University of Johannesburg, APK campus, 2006, Johannesburg, South Africa. ${ }^{4}$ Botany and Microbiology Department, College of Science, King Saud University, P.O. Box 2455, Riyadh 11451, Saudi Arabia. ${ }^{5}$ Timber Trees Research Department, Sabahia Horticulture Research Station, Horticulture Research Institute, Agriculture Research Center, Alexandria, Egypt. ${ }^{6}$ Department of Pharmacognosy with Medicinal Plant Unit, Medical University of Lublin, Lublin, Poland.

Received: 5 March 2017 Accepted: 12 January 2018

Published online: 22 January 2018

\section{References}

1. Burt S. Essential oils: their antibacterial properties and potential applications in foods - a review. Int J Food Microbiol. 2004;94:223-53.

2. Bakkali F, Averbeck S, Averbeck D, Idaomar M. Biological effects of essential oils - a review. Food Chem Tox. 2008;46:446-75.

3. Gilles M, Zhao J, An M, Agboola S. Chemical composition and antimicrobial properties of essential oils of three Australian eucalyptus species. Food Chem. 2010;119:731-7.

4. Elansary HO, Ashmawy NA. Essential oils of mint between benefits and hazards. J Essent Oil Bear PI. 2013:16:429-38.

5. Elansary HO, Mahmoud EA. Basil cultivar chemotyping still favored over genotyping using core barcodes and possible resources of antioxidants. J Essent Oils Res. 2015a;27:82-7.

6. Elansary $\mathrm{HO}$, Mahmoud EA. In vitro antioxidant and antiproliferative activities of six international basil cultivars. Nat Prod Res. 2015b;29:2149-54.

7. Wei A, Shibamoto T. Antioxidant activities and volatile constituents of various essential oils. J Agric Food Chem. 2007:55:1737-42.

8. Elansary HO, Yessoufou K, Mahmoud EA, Skalicka-Woźniak K. In vitro antioxidant and antimicrobial effects of Ceratostigma plumbaginoides. Nat Prod Comm. 2016;11:1455-8.

9. Farjon A. Nomenclature of the Mexican cypressor "cedar of Goa", Cupressus lusitanica mill. (Cupressaceae). Taxon. 1993;42:81-4.

10. Graniti A. Cypress canker: a pandemic in progress. Annu Rev Phytopathol. 1998;36:91-114.

11. Manimaran S, Themozhil S, Nanjan MJ, Suresh B. Chemical composition and antimicrobial activity of cone volatile oil of Cupressus macrocarpa Hartwig from Nilgiris, India. Nat Prod Sci. 2007;13:279-82.

12. Duke J. Phytochemical database (Phytochem DB) Beltsville MD: USDA-ARS NGRL, Beltsville agricultural research center. 2004.

13. Zavarin E, Smith LV, Bicho JG. Tropolones of Cupressaceae-III. Phytochemistry. 1967;6:1387-94.

14. Floreani SA, Retamar JA, Gros EG. Terpenoids of the essential oils from species of Cupressus. An Asoc Quím Argent. 1982;70:663-7. 
15. Malizia RA, Cardell DA, Molli JS, Gonzalez S, Guerra PE, Grau RJ. Volatile constituents of the leaf oils from the Cupressaceae Family: part I. Cupressus macrocarpa Hartw., C. arizonica Greene and C. torulosa don species growing in Argentina. J Essent Oil Res. 2000;12:59-63.

16. Cool LG. Sesquiterpenes from Cupressus macrocarpa foliage. Phytochemistry. 2005;66:249-60.

17. El-Ghorab AH, El-Massry KF, Shaaban HA. Effect of drying on the chemical composition of the Egyptian Cupressus macrocarpa (Hartw.Ex Gordon) essential oils and their biological characteristics. J Essent Oil Bear PI. 2007;10:399-411.

18. Zavarin E, Lawrence L, Thomas MC. Chemosystematics of Cupressus. IV Compositional variations of leaf monoterpenoids in Cupressus macrocarpa, C. pygmaea, C. goveniana, C. abramsiana and C. sargentii. Phytochemistry. 1971;10:379-93.

19. Fahed L, Khoury M, Stien D, Ouaini N, Eparvier V, El Beyrouthy M. Essential oils composition and antimicrobial activity of six conifers harvested in Lebanon. Chem Biodivers. 2017;14(2)

20. Silva J, Abebe W, Sousa SM, Duarte VG, Machado MIL, Matos FJA. Analgesic and anti-inflammatory effects of essential oils of eucalyptus. Bioresour Technol. 2003;89:277-83.

21. Sebei K, Sakouhi F, Herchi W, Khouja ML, Boukhchina S. Chemical composition and antibacterial activities of seven eucalyptus species essential oils leaves. Biol Res. 2015;48:7.

22. Ramezani $H$, Singh HP, Batish DR, Kohli RK. Antifungal activity of the volatile oil of Eucalyptus Citriodora. Fitoterapia. 2002;73:261-2.

23. Singh HP, Batish DR, Setia N, Kohli RK. Herbicidal activity of volatile oils from Eucalyptus citriodora against Parthenium hysterophorus. Ann App Biol. 2005; 146:89-94

24. Batish DR, Singh HP, Kohli RK, Kaur S. Eucalyptus essential oil as a natural pesticide. Forest Ecol Manag. 2008;256:2166-74.

25. Habila N, Agbaji AS, Ladan Z, Bello IA, Haruna E, Dakare MA, Atolagbe TO. Evaluation of in vitro activity of essential oils against Trypanosoma brucei brucei and Trypanosoma evansi. J Parasitol Res. 2010:534601. 5 pages, https://doi.org/10.1155/2010/534601

26. Singh HP, Kaur S, Negi K, Kumari S, Saini V, Batish DR, Kohli RK. Assessment of in vitro antioxidant activity of essential oil of Eucalyptus citriodora (lemonscented eucalypt; Myrtaceae) and its major constituents. LWT - Food Sci Technol. 2012:48:237-41.

27. Batish DR, Singh HP, Setia N, Kaur S, Kohli RK. Chemical composition and inhibitory activity of essential oil from decaying leaves of Eucalyptus citriodora. Z Naturforsch C. 2006;61:465-71.

28. Mittal A, Ali M. Volatile composition of the leaves of Eucalyptus citriodora hook. Int J Res Ayurveda Pharm. 2011;2:509-11.

29. Abd El-Mageed AA, Osman AK, Tawfik AQ, Mohammed HA. Chemical composition of the essential oils of four eucalyptus species (Myrtaceae) from Egypt. Res J Phytochem. 2011;5:115-22.

30. Chaibi A, Ababouch LH, Belasri K, Boucetta S, Busta FF. Inhibition of germination and vegetative growth of Bacillus cereus T and Clostridium botulinum 62A spores by essential oils. Food Microbiol. 1997:14:161-74.

31. Fiori ACG, Schwan-Estrada KRF, Stangarlin JR, Vida JB, Scapim CA, Cruz MES, Pascholati SF. Antifungal activity of leaf extracts and essential oils of some medicinal plants against Didymella bryoniae. J Phytopathol. 2000;148:483-7.

32. Delaquis PJ, Stanich K, Girard B, Mazza G. Antimicrobial activity of individual and mixed fractions of dill, cilantro, coriander and eucalyptus essential oils. Int J Food Microbiol. 2002;74:101-9.

33. HJS D, Thind TS, Chander M. Relative activity of essential oils from plants against Penicillium digitatum causing post-harvest fruit rot of Kinnow mandarin. Plant Dis Res. 2004;19:140-3.

34. Moreira MR, Ponce AG, del Valle CE, Roura SI. Inhibitory parameters of essential oils to reduce a foodborne pathogen. Lebensm Wiss Technol. 2005:38:565-70

35. Lee OG, Choi GJ, Jang KS, Lim HK, Cho KY, Kim JC. Antifungal activity of five plant essential oils as fumigant against postharvest and soilborne plant pathogenic fungi. Plant Pathol J. 2007;23:97-102

36. Somda I, Leth V, Sereme P. Antifungal effect of Cymbopogon citratus, Eucalyptus camaldulensis and Azadirachta indica oil extracts on sorghum feedborne fungi. Asian J Plant Sci. 2007:6:1182-9.

37. Sartorelli P, Marquioreto AD, Amaral-Baroli A, Lima ME, Moreno PR. Chemical composition and antimicrobial activity of the essential oils from two species of eucalyptus. Phytother Res. 2007;21:231-3.
38. Tripathi P, Dubey NK, Shukla AK. Use of some essential oils as postharvest botanical fungicides in the management of grey mould of grapes caused by Botrytis Cinerea. World J Microbiol Biotechnol. 2008:24:39-46.

39. Brooker MIH, Kleinig DA. Field Guide to Eucalyptus, vol. 1, Third edition Bloomings, Melbourne, South-eastern Australia. 2006.

40. Salem MZM, Ali HM, El-Shanhorey NA, Abdel-Megeed A. Evaluation of extracts and essential oil from Callistemon Viminalis leaves: antibacterial and antioxidant activities, total phenolic and flavonoid contents. Asian Pac Trop Med. 2013;6:785-91.

41. Salem MZ, Ashmawy NA, Elansary HO, El-Settawy AA. Chemotyping of diverse eucalyptus species grown in Egypt and antioxidant and antibacteria activities of its respective essential oils. Nat Prod Res. 2015;29(7):681-5.

42. Davies NW. Gas chromatographic retention indices of monoterpenes and sesquiterpenes on methyl silicone and Carbowax 20M phases. J chromatography, A. 503, 1-24. British pharmacopeia. 1990,(Vol. II). HMSO: London.

43. Adams RP. Identification of essential oil components by gas chromatograph/ quadrupole mass spectroscopy. Carol Stream, IL: Allured Publishing; 1995.

44. Espinel-Ingroff A. In vitro fungicidal activities of voriconazole, itraconazole, and amphotericin B against opportunistic moniliaceous and dematiaceous fungi. J Clin Microbiol. 2001:39:954-8.

45. Tepe B, Daferera D, Sokmen A, Sokmen M, Polissiou A. Antimicrobial and antioxidant activities of the essential oil and various extracts of Salvia tomentosa miller (Lamiaceae). Food Chem. 2005;90:333-40.

46. Giatropoulos A, Pitarokili D, Papaioannou F, Papachristos DP, Koliopoulos G, Emmanouel N, Tzakou O, Michaelakis A. Essential oil composition, adult repellency and larvicidal activity of eight Cupressaceae species from Greece against Aedes albopictus (Diptera: Culicidae). Parasitol Res. 2013;112:1113-23.

47. Adams RP. Geographic variation in the leaf essential oils of Hesperocyparis (cupressus) abramsiana, $H$. goveniana and $H$. macrocarpa: systematic implications. Phytologia. 2009;91:226-43.

48. Jang M, Kim J, Yoon KA, Lee SH, Park CG. Biological activity of Myrtaceae plant essential oils and their major components against Drosophila Suzukii (Diptera: Drosophilidae). Pest Manag Sci. 2017:73:404-9.

49. Maciel MV, Morais SM, Bevilaqua CML, Silva RA, Barros RS, Sousa RN, Sousa LC, Brito ES, Souza-Neto MA. Chemical composition of eucalyptus spp. essential oils and their insecticidal effects on Lutzomyia longipalpis. Vet Parasitol. 2010;167:1-7.

50. Bossou AD, Ahoussi E, Ruysbergh E, Adams A, Smagghe G, De Kimpe N, Avlessi F, Sohounhloue DCK, Mangelinckx S. Characterization of volatile compounds from three Cymbopogonspecies and Eucalyptus citriodora from Benin and their insecticidal activities against Tribolium castaneum. Ind Crop Prod. 2015:76:306-17.

51. Hussein HS, Salem MZM, Soliman AM. Repellent, attractive, and insecticidal effects of essential oils from Schinus terebinthifolius fruits and Corymbia citriodora leaves on two whitefly species, Bemisia tabaci and Trialeurodes ricini. Sci Hort. 2017:216C:111-9.

52. Elaissi A, Salah KH, Mabrouk S, Larbi KM, Chemli R, Harzallah-Skhiri F. Antibacterial activity and chemical composition of 20 eucalyptus species' essential oils. Food Chem. 2011;129:1427-34

53. Low D, Rawal BD, Griffin WJ. Antibacterial action of the essential oils of some Australian Myrtaceae with special references to the activity of chromatographic fractions of oil of Eucalyptus citriodora. Planta Med. 1974;26:184-9.

54. AidiWannes W, Mhamdi B, Sriti J, Ben Jemia M, Ouchikh O, Hamdaoui G, Kchouk ME, Marzouk B. Antioxidant activities of the essential oils and methanol extracts from myrtle (Myrtus communis Var. Italica L.) leaf, stem and flower. Food Chem Tox. 2010:48:1362-70.

55. Ayinde BA. Chapter 46 - Eucalyptus (Eucalyptus citriodora hook., Myrtaceae) oils. Essential Oils in Food Preservation, Flavor and Safety Pages. 2016:413-9. 